Utah State University

DigitalCommons@USU

1969

\title{
Selective Breeding of Honeybees for Alfalfa Pollen Collection: Sixth Generation and Outcrosses
}

O. Mackensen

William P. Nye

Utah State University

Follow this and additional works at: https://digitalcommons.usu.edu/piru_pubs

Part of the Entomology Commons

\section{Recommended Citation}

Mackensen, O., and W. P. Nye. 1969. Selective Breeding of Honeybees for Alfalfa Pollen Collection: Sixth Generation and Outcrosses. J. Apic. Res. 8(1):9-12, tables.

This Article is brought to you for free and open access by the Pollinating Insects Research Unit at DigitalCommons@USU. It has been accepted for inclusion in All PIRU Publications by an authorized administrator of DigitalCommons@USU. For more information, please contact digitalcommons@usu.edu.

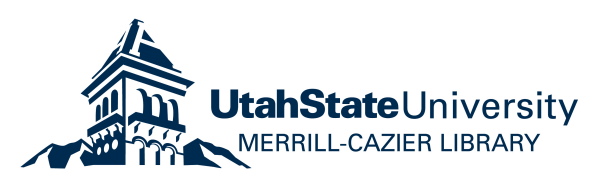




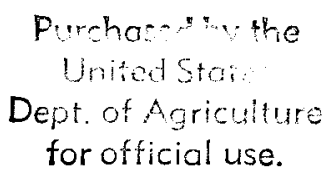

Journal of Apicultural Research 8(1) : 9-12 (1969)

\title{
SELECTIVE BREEDING OF HONEYBEES FOR ALFALFA POLLEN COLLECTION: SIXTH GENERATION AND OUTCROSSES*
}

\author{
Otto Mackensen and William P. NYE \\ Entomology Research Division, Agricultural Research Service, U.S.D.A., Baton Rouge, \\ Louisiana 70803 and Logan, Utah 84321, U.S.A.
}

Manuscript received for publication 18th December 1968

\begin{abstract}
Summary
Five groups of honeybee colonies were tested for their tendency to collect alfalfa pollen. One group was the sixth generation of a line with a strong tendency to collect this pollen (high line); another was the sixth generation of a line with a low tendency to collect it (low line). In these two groups an average of $86 \%$ and $8 \%$, respectively, of the pollen collectors collected alfalfa pollen; this represented little improvement over the fifth generation (Nye \& Mackensen, 1968). A third group was a commercial strain (which ranked low, $31 \%$ ), but the fourth (an outcross of high-line queens to drones of the commercial strain) and a fifth (an outcross of high-line drones to queens of another stock) ranked intermediate, at $52 \%$ and $59 \%$, respectively, and were significantly higher than the commercial strain. The number of alfalfa pollen collectors was highest (29) in the high line; it was the same (18) in both outcrosses, this being slightly but not significantly higher than in the commercial strain (16). The number of nectar collectors and the yield of honey were roughly proportional to the amount of inbreeding in each group.
\end{abstract}

\section{Introduction}

In five generations of selective breeding of honeybees (Apis mellifera) foraging on affalfa (Medicago sativa), we have succeeded in developing one line that ranks high and one line that ranks low in alfalfa pollen collectors (APC). When the fifth generation of these bees was tested in $1966,85 \%$ and $18 \%$ of the pollen-collecting bees in the high and low lines, respectively, were collectors of alfalfa pollen (Nye \& Mackensen, 1965, 1968; Mackensen \& Nye, 1966). Also, from the results of hybridizations between the two lines and backcrosses, we concluded that the characteristic of collecting alfalfa pollen is probably dependent on many genes that have additive effects.

The present paper reports on the sixth generation of selection and the results obtained in outcrosses between the High-APC line and unrelated bees.

\section{Material and Methods}

Our breeding and testing methods were virtually the same as those used with the fifth generation (Nye \& Mackensen, 1968). The breeding was done at Baton Rouge, Louisiana and the testing at Logan, Utah. Fifteen colonies of each of the following were tested: High-APC line, Low-APC line, Strain B, an unrelated commercial strain, an outcross of High-APC queens to drones of Strain B (High-APC queen outcross), an outcross of High-APC drones to unrelated queens from still another source (HighAPC drone outcross).

As in previous generations, three sets of matings were used within each inbred line. The virgin queens and drones of each such set came from different breeder

* In co-operation with Louisiana and Utah Agricultural Experiment Stations. 
colonies, selected from among the colonies of the fifth generation tested in 1966-and usually from colonies of different sets of the previous generation-to minimize inbreeding. In the High-APC queen outcross, virgins from two breeder colonies were mated with drones of Strain B collected at random from a number of colonies. In the High-APC drone outcross, the drones of a single queen were mated with virgins reared from a queen of the YR inbred line that had been mated with drones of the YD inbred line. These two lines are somewhat related, and are maintained at the Bee Stock Investigations Laboratory at Baton Rouge, Louisiana. The Strain B queens were obtained directly from a commercial beekeeper.

Strain B queens were allowed to mate naturally; other matings were accomplished by instrumental insemination. Also, the matings of the inbred line were individual, but all others were multiple-drone matings with $8 \mu l$ of semen. The instrumentally inseminated queens were pre-tested at Baton Rouge to determine brood viability, and the best of each were selected to make up the 15 colonies for each test group.

As in our earlier work, the testing of preference for alfalfa pollen was done in fields of alfalfa grown for seed at Logan, Utah. The queens were introduced to the test colonies between 25th April and 2nd June. Then, between 12th July and 3rd August, returning field bees were sampled about twice weekly until 8 samples had been taken from each colony, by sucking the bees into a bag with a vacuum device. The samples were killed, refrigerated, and later divided into pollen collectors and non-pollen collectors, and the pollen collectors were then sorted by the floral source of the pollen they carried. In this paper, we will consider only the number of non-pollen collectors, the total number of pollen collectors, the number of collectors of alfalfa pollen, the percentage of pollen collectors that were collectors of alfalfa pollen, and the yield of honey.

Analysis of variance and orthogonal comparisons were used in the statistical treatment of all classes of data except yield of honey. Percentages were converted to arc sine.

\section{Results and Discussion}

The average performance of the 15 colonies in each test group is given in Table 1 , and the results of the analysis of variance and orthogonal comparisons are given in Table 2. The analysis of variance showed a highly significant difference among groups for almost all classes of data analysed and also among data taken on different dates; the exception was the average percentage of alfalfa pollen collectors (arc sine), which was significant at the $5 \%$ level. Data obtained on different dates were affected by weather, the time of day the samples were taken, the growing season, the competition from other plants, injurious insects, and insecticides. Interaction between test groups and dates was always highly significant.

The yield of honey was roughly proportional to the number of non-pollen collectors, most of which were probably collectors of nectar; it demonstrated the unfavourable effect of inbreeding, and the vigour of hybrids. Inbreeding can reduce the number of worker bees severely, both because of the lethal action of sex alleles and because of its general weakening effect. Thus the highest yield recorded was for the High-APC drone outcross, a three-way hybrid with queens (themselves hybrid between the YR and YD inbred lines) mated to unrelated High-APC drones; this made both queens and workers of the test colonies hybrid. Strain B was not hybrid, and probably did not have quite the vigour of the three-way hybrid; this might account for its lower yield. In the High-APC queen outcross, the workers were hybrid, but the queens were inbred. 
TABLE 1. Results obtained from tests of five groups of colonies in 1967 at Logan, Utah (15 colonies per group; 8 observations, per colony)

\begin{tabular}{lccccc}
\hline \multicolumn{1}{c}{ Test group } & $\begin{array}{c}\text { No. non- } \\
\text { pollen } \\
\text { collectors }\end{array}$ & $\begin{array}{c}\text { No. pollen } \\
\text { collectors }\end{array}$ & $\begin{array}{c}\text { No. alfalfa } \\
\text { pollen } \\
\text { collectors }\end{array}$ & $\begin{array}{c}\% \text { alfalfa } \\
\text { pollen } \\
\text { collectors }\end{array}$ & $\begin{array}{c}\text { Honey yield } \\
\text { per colony } \\
(\mathrm{kg})\end{array}$ \\
\hline High-APC line & 97 & 34 & 29 & 86 & 27 \\
Low-APC line & 89 & 46 & 4 & 8 & 29 \\
High-APC queen outcross & 102 & 35 & 18 & 52 & 44 \\
High-APC drone outcross & 130 & 30 & 18 & 59 & 82 \\
Strain B & 115 & 49 & 16 & 31 & 50 \\
\hline
\end{tabular}

The two lines with both queens and workers inbred were low in yield. Thus, absence of inbreeding in a colony as a whole is an important factor in the number of nectar collectors and the yield of honey.

Although Strain B had the highest average number of pollen collectors, only $31 \%$ collected alfalfa pollen. The Low-APC line had almost as many pollen collectors but, as expected, few collected alfalfa pollen. The High-APC line had a small total number of pollen collectors, but it ranked by far the highest in number of alfalfa pollen collectors. In the two outcrosses, the number of alfalfa pollen collectors was only slightly greater than in Strain B, but in percentage of alfalfa pollen collectors they stood about intermediate between the High-APC line and Strain B, and were significantly higher than Strain B. Therefore the preference for alfalfa was in part transmitted to the outcross progeny. Moreover, both a high number of pollen collectors and a high preference for alfalfa pollen are important.

The selection for a sixth generation in the inbred lines produced little increase over the fifth generation in the percentage of alfalfa pollen collectors. In the HighAPC line, the average percentage increased from $85 \%$ to $86 \%$; in the Low-APC line, it decreased from $18 \%$ in the fifth generation to $8 \%$ in the sixth, about the same as the $7 \cdot 6 \%$ of the fourth generation (Mackensen \& Nye, 1966). Apparently a plateau has

TABLE 2. Analysis of variance of four types of data from colonies of the sixth generation and outcrosses tested in 1967 for their tendency to collect alfalfa pollen (Logan, Utah)

\begin{tabular}{lccccc}
\hline & & \multicolumn{4}{c}{ Mean squares } \\
\cline { 3 - 6 } \multicolumn{1}{c}{ Source of variance } & d.f. & $\begin{array}{c}\text { Non-pollen } \\
\text { collectors }\end{array}$ & $\begin{array}{c}\text { Total pollen } \\
\text { collectors }\end{array}$ & $\begin{array}{c}\text { Alfalfa pollen } \\
\text { collectors }\end{array}$ & $\begin{array}{c}\% \text { Alfalfa } \\
\text { pollen } \\
\text { collectors }\end{array}$ \\
\hline Test groups & 4 & $30931 \dagger$ & $8135 \dagger$ & $10025 \dagger$ & $59900 \dagger$ \\
$\quad$ Inbreds vs. others & 1 & $75460 \dagger$ & 415 & 137 & 977 \\
$\quad$ High line vs. Low line & 1 & 3773 & $8796^{*}$ & $39398 \dagger$ & $201637 \dagger$ \\
Outcrosses vs. Strain B & 1 & 19 & $22055 \dagger$ & 560 & $34364 \dagger$ \\
$\quad$ High queen vs. High drone & & & & & \\
$\quad$ outcross & 1 & $44472 \dagger$ & 1274 & 6 & 2621 \\
Error (a) & 70 & 4461 & 1627 & 596 & 1073 \\
Dates & 7 & $21911 \dagger$ & $12247 \dagger$ & $2252 \dagger$ & $736^{*}$ \\
Groups $\times$ dates & 28 & $4728 \dagger$ & $2064 \dagger$ & $1014 \dagger$ & $2222 \dagger$ \\
Error (b) & 490 & 1617 & 503 & 246 & 358 \\
Total & 599 & 2527 & 895 & 412 & 931 \\
\hline
\end{tabular}

* Significant at the $5 \%$ level of confidence

$\uparrow$ Significant at the $1 \%$ level of confidence 
been reached in both lines, though the percentage is affected by differences from year to year in the availability of pollen from competing plants and by many other factors. The high uniformity among the three sets of matings within lines is further evidence that a plateau has been reached. In the High-APC line, the percentages of alfalfa pollen collectors in colonies of the three sets were $87.6 \%, 87.5 \%$ and $82.2 \%$; in the Low-APC line, the percentages were $6.8 \%, 9.0 \%$ and $7.6 \%$. Thus further selection will probably do no more than hold these lines at their present levels.

The main purpose of our tests of outcrosses was to determine the practicability of using outcrosses for the commercial production of queens for colonies to be used for alfalfa pollination. The High-APC drone outcross would be the better of the two, but it would require instrumental insemination or some control of natural mating. The High-APC queen outcross would be relatively easy to use because no special control of mating would be required, and only one or two breeder queens of the HighAPC line would be needed. Also, mating with drones of the queen breeder's own strain would restore vigour and viability to the worker progeny, which would be hybrids. However, our results do not particularly encourage the use of this method. The outcrosses put $11 \%$ more alfalfa pollen collectors in the field than did the commercial strain, but the difference was not statistically significant; a real $11 \%$ increase in effectiveness of bees in alfalfa seed production might, however, be worth while.

We have shown that the tendency to collect alfalfa pollen in preference to other pollens is inherited, and we have selected a line of bees with a high preference for alfalfa pollen. But it is still to be determined whether these bees bring about a better seed set than other bees, and whether their commercial exploitation is feasible. In 1967 we set up an experiment to compare the seed-setting ability of the High-APC line with that of commercial bees, but were unable to obtain meaningful data on account of insufficient control of insecticide applications and other cultural practices. Further tests are planned. We are also furnishing queens of the High-APC line to commercial beekeepers and research agencies, for evaluation of outcrosses under commercial conditions.

\section{References}

MACKensen, O. \& NYE, W. P. (1966) Selecting and breeding honeybees for collecting alfalfa pollen. J. apic. Res. 5(2) : 79-86

Nye, W. P. \& Mackensen, O. (1965) Preliminary report on selection and breeding of honeybees for alfalfa pollen collection. J. apic. Res. 4(1) : 43-48

(1968) Selective breeding of honeybees for alfalfa pollen: fifth generation and backcrosses. J. apic. Res. $7(1): 21-27$ 